\title{
A Qualitative Method Proposal for the Study of Strategy as Practice
}

\author{
Uma Proposta de Método Qualitativo para o Estudo da Estratégia como \\ Prática
}

\author{
Leonardo Lemos da Silveira Santos ${ }^{1}$ \\ César Tureta ${ }^{2}$ - \\ Bruno Felix ${ }^{3}$ (ㅇ
}

\section{ABSTRACT}

Purpose: recently, the strategy as practice approach has sought to overcome the micro/macro dichotomy existing in its literature, as well as to better integrate the dimensions of praxis, practice and practitioner. To fill this gap, the aim of the paper is to discuss potential methods to guide empirical studies of strategy as practice (SAP). Method: the paper proposes a method based on an extensive literature review. Phenomenology, grounded theory, ethnography, and narratives are discussed, and their components are presented in the context of strategy as practice studies. Results: the presented method articulates four approaches. Phenomenology is used to enhance the understanding of strategist experiences. Grounded theory is considered a method to develop theories about the studied phenomenon. Ethnography is used to contextualize the daily practices of strategists. Narratives are the path to access the stories of the strategists. Conclusion: the proposed method may be useful to overcome micro/ macro dichotomy existing in strategy as practice literature and to integrate praxis, practice and practitioner dimensions.

Keywords: strategy as practice; ethnography; grounded theory; narrative; qualitative research.
1. Universidade Federal de Juiz de Fora, Departamento de Administração, Governador Valadares, Minas Gerais, Brazil.

2. Universidade Federal do Espírito Santo, Programa de Pós-graduação em Administração, Vitória, ES, Brazil. 3. FUCAPE Business School, Vitória, ES, Brazil.

Cite as: Santos, L. L. da S., Tureta, C., \& Felix, B. (2021). A qualitative method proposal for the study of strategy as practice. Revista de Administração Contemporânea, 25(2), el90353. https://doi.org/10.1590/1982-7849rac2021190353.en

\section{RESUMO}

Objetivo: recentemente, a abordagem da estratégia como prática tem buscado superar a dicotomia micro/macro existente na sua literatura, bem como integrar melhor as dimensóes da práxis, prática e praticante. Para preencher esta lacuna, o objetivo deste artigo é discutir potenciais métodos para guiar estudos empíricos de estratégia como prática. Métodos: com base em uma extensa revisão de literatura, desenvolvemos um método baseado na fenomenologia, na teoria fundamentada, na etnografia e na análise de narrativas. Esses componentes são apresentados e discutidos no trabalho tendo em vista o contexto dos estudos de estratégia como prática. Resultados: o método apresentado envolve a articulação de quatro abordagens. A fenomenologia é usada para ampliar o entendimento a respeito das experiências dos estrategistas. A teoria fundamentada é considerada como um caminho para desenvolver teorias sobre o fenômeno estudado. A etnografia é empregada como um meio para contextualizar as práticas diárias dos estrategistas. Por fim, as narrativas são o caminho para acessar as histórias dos estrategistas. Conclusóes: o método proposto pode ser útil para superar a dicotomia micro/ macro existente na literatura de estratégia como prática e para integrar as dimensóes práxis, prática e praticante.

Palavras-chave: estratégia como prática; etnografia; teoria fundamentada; narrativas; pesquisa qualitativa.

\begin{tabular}{|c|c|c|c|c|c|c|c|c|c|}
\hline & 1 & 2 & 3 & 4 & 5 & 6 & 7 & 8 & 9 \\
\hline $1^{\text {st }}$ round & (x) & $\stackrel{9}{\stackrel{9}{2}}$ & $x$ & (x) & (x) & $\stackrel{p}{2}$ & & & \\
\hline $2^{\text {nd }}$ round & $\frac{9}{2}$ & & & & & & & & \\
\hline $3^{\text {rd }}$ round & $\stackrel{\varphi}{2}$ & & & & & & & & \\
\hline
\end{tabular}




\section{INTRODUCTION}

In the last two decades, strategy as practice (SAP) has emerged as a distinctive approach in strategic management (Golsorkhi, Rouleau, Seidl, \& Vaara, 2010; Jarzabkowski, 2005; Jarzabkowski, Balogun, \& Seidl, 2007; Jarzabkowski \& Spee, 2009; Johnson, Langley, Melin, \& Whittington, 2007; Johnson, Melin, \& Whittington, 2003; Vaara \& Whittington, 2012; Whittington, 1996). Since its inception, it has been positioned as an alternative to the mainstream strategy research and as a more comprehensive analysis of what takes place in strategy planning, implementation, and other activities that deal with the thinking and doing of strategy (Golsorkhi et al., 2010). Researchers' attention has shifted from strategy as something that an organization has (or should have) to strategizing as a process, that is, an everyday practice understood as the doing of strategy (Jarzabkowski et al., 2007; Johnson et al., 2003; Whittington, 1996). The key insight of SAP studies has been the idea that strategy work relies on organizational and other practices that affect both the process and the outcome of strategies (Jarzabkowski et al., 2007; Jarzabkowski \& Spee, 2009; Johnson et al., 2003; Vaara \& Whittington, 2012). This conceptual reorientation offers the possibility of a deeper level of explanation regarding the nature of strategic activities "because it focuses research attention on the situated social practices that are enacted and re-enacted in the doing of strategy" (Rasche \& Chia, 2009, p. 713).

Currently it is possible to find under the label of strategy as practice a wide variety of theoretical essays and empirical research (Golsorkhi et al., 2010; Jarzabkowski et al., 2007; Jarzabkowski \& Spee, 2009; Johnson et al., 2007; Vaara \& Whittington, 2012). Due to the empirical effort already made, we know a lot about how top managers strategize (Jarzabkowski, 2005), how boards do strategy (Hendry, Kiel, \& Nicholson, 2010), and how middle managers can and do contribute to strategy making (Rouleau, 2005). From the theoretical point of view, different articulations have already been built between SAP perspective and theories of practice (Golsorkhi et al., 2010; Seidl \& Whittington, 2014): Jarzabkowski (2005) explored activity theory; Whittington (2010) discussed structuration theory; Denis, Langley, and Rouleau (2007) pointed the potential contributions from actor-network theory, theories of social practice, and convention theory; Suddaby, Seidl and Lê (2013) unveiled different ways in which neo-institutionalism and SAP could complement each other.

Regarding the method aspect, explicit contributions have been relatively less common (Golsorkhi et al., 2010). Balogun, Huff and Johnson (2003) published the first paper to address this issue directly and suggest specific method approaches (interactive discussion groups, self-reports, and practitioner-led research). Johnson, Langley, Melin and Whittington (2007) dedicated a chapter providing illustrations of important method choices and their respective advantages and disadvantages. Golsorkhi, Rouleau, Seidl and Vaara (2010) presented five different methodological tracks in strategy-as-practice research. To date, with respect to data production, strategy-as-practice researchers have shown a strong orientation toward qualitative methods.

Although many theoretical advancements have been made (e.g., Gehman et al., 2018; Golsorkhi et al., 2010; Jarzabkowski, 2005; Jarzabkowski et al., 2007; Johnson et al., 2003; Seidl \& Whittington, 2014; Tsoukas, 2018; Whittington, 2006), what has proven more difficult for strategy-as-practice researchers is applying these theoretical resources in systematic empirical research (Seidl \& Whittington, 2014; Vaara \& Whittington, 2012). Therefore, novel methods techniques that can capture the depth of the strategizing process are still needed (Jarzabkowski et al., 2007; Vaara \& Whittington, 2012). This call for innovative approaches does not necessarily mean that we have to develop entirely new methods. It suggests, rather, "that we look at them through a 'practice lens' and use innovative ways to approach managers and reconstruct their strategizing activities and roles" (Golsorkhi et al., 2010, p. 10).

In this sense, the paper aims to discuss potential methods to guide empirical studies of SAP. We will develop the method based on four research traditions already used in practice based empirical studies. Although they are not novel, they will be linked in a complementary way, through a strategy-as-practice lens. We propose a framework that brings together: Heiddeger's interpretative phenomenology (Chia \& Holt, 2006; Gill, 2014; Küpers, 2009; Tsoukas, 2010), ethnography (Atkinson, Coffey, Delamont, Lofland, \& Lofland, 2001; Cunliffe, 2010, 2015; Rasche \& Chia, 2009), narrative of practice (De La Ville \& Mounoud, 2010; Fenton \& Langley, 2011; Laslett, 1999; Rouleau, 2010), and grounded theory (Bryant, 2017; Charmaz, 2000, 2006; Corley, 2015; Goulding, 2002; Hendry et al., 2010; Strauss \& Corbin, 1998).

We argue that these research traditions taken together constitute a multifaceted approach contributing to enrich the methodological strategy-as-practice agenda in two complementary ways. First, it reinforces the need to align methods approach, theoretical choices, and ontoepistemological assumptions that guide the fieldwork. Our proposal resonates with recent calls for more ontological and epistemological depth in SAP research (Chia \& Rasche, 2010; Feldman \& Orlikowski, 2011; Gherardi, 2009; Orlikowski, 2010; Tsoukas, 2010; Vaara \& Whittington, 2012). Second, aware that it is impossible to access all aspects of strategy practice and that the researcher's view is always partial and selective, we argue that it is necessary to design 
a multi-method research so that we can see (and analyze) the strategizing from multiple points of view (Feldman \& Orlikowski, 2011; Fook, 2002). Here we engage in the debate on how to choose appropriate method approaches to study empirically what social practices of strategizing are about (Seidl \& Whittington, 2014; Vaara \& Whittington, 2012). Specifically, we seek to describe how ethnography, narratives of practice, and grounded theory can be used together to help researchers to deal with the challenge of going beyond in vivo descriptions to link micro-level practices with more macrolevel outcomes. It is important to note that the framework could be used flexibly as it is not a cookbook but provides guidance tools that may be customized according to the problem and the context of the research (Gehman et al., 2018).

\section{TO STUDY STRATEGIZING AS A PRACTICE}

One of the main contributions of the practice turn (Reckwitz, 2002; Schatzki, Knorr-Cetina, \& Savigny, 2001) was its attempts to overcome the micro/macro distinction (Feldman \& Orlikowski, 2011; Felix, Mello, \& von Borell, 2018; Seidl \& Whittington, 2014). It argues that a dynamic practice field should be the starting point for social analysis (Schatzki, 2005). Micro and macro are seen as secondary effects of the practice field (Chia \& MacKay, 2007). In this perspective, which is consistent with a becoming ontology as coined by Chia (1995), the phenomena are not fixed but should be explored empirically as being consistently ephemeral. A truly practical approach is particularly powerful when it takes seriously the interaction of the 'what' practices are used, 'who' is engaged in the practices, and 'how' the practices are carried out (Jarzabkowski, Kaplan, Seidl, \& Whittington, 2016, p. 248).
SAP perspective has focused on microactivities, giving little attention to the broader issues related to the institutional level (Seidl \& Whittington, 2014; Suddaby, Seidl, \& Lê, 2013) and to the nature of strategic work (Hydle, 2015). In this sense, there is a need to understand the macroinstitutional nature of the strategizing and how the activities of this practice are embedded in a broader social context (Jarzabkowski et al., 2016; Vaara \& Whittington, 2012), which can generate significant institutional transformations (Johnson, Smith, \& Colding, 2010). Fascination with the detailed understanding of local praxis can produce what has been called 'micro-isolationism,' whereby a local empirical instance is interpreted wholly in terms of what is evidently present, cut off from the larger phenomena that make it possible (Feldman \& Orlikowski, 2011; Jarzabkowski et al., 2016; Kouamé \& Langley, 2018; Seidl \& Whittington, 2014; Vaara \& Whittington, 2012).

Traditionally, SAP research has employed methods informed by ethnography (e.g., Iszatt-White, 2010; Samra-Fredericks, 2003), grounded theory (e.g., Hendry et al., 2010), and phenomenology joint narratives research (e.g., Küpers, Mantere, \& Statler, 2013). Each of these approaches enables in depth exploration of certain strategizing dimensions (praxis, practices, or practitioners) and certain levels of analysis (micro, meso, or macro). Nevertheless, when applied alone, they have some limitation in understanding strategy as practice. Despite the promising results of the practice-based theories in SAP literature, "it is time to do research with methodological frames design from a practice perspective" (Jarzabkowski et al., 2007 p. 22). We argue that the method design discussed in this paper is long-range because it allows apprehending different levels of analysis and to deal with praxis-practices-practitioners dimensions that are central to SAP studies (see Whittington, 2006; Wolf \& Floyd, 2017). Figure 1 illustrates the method developed in the present study.

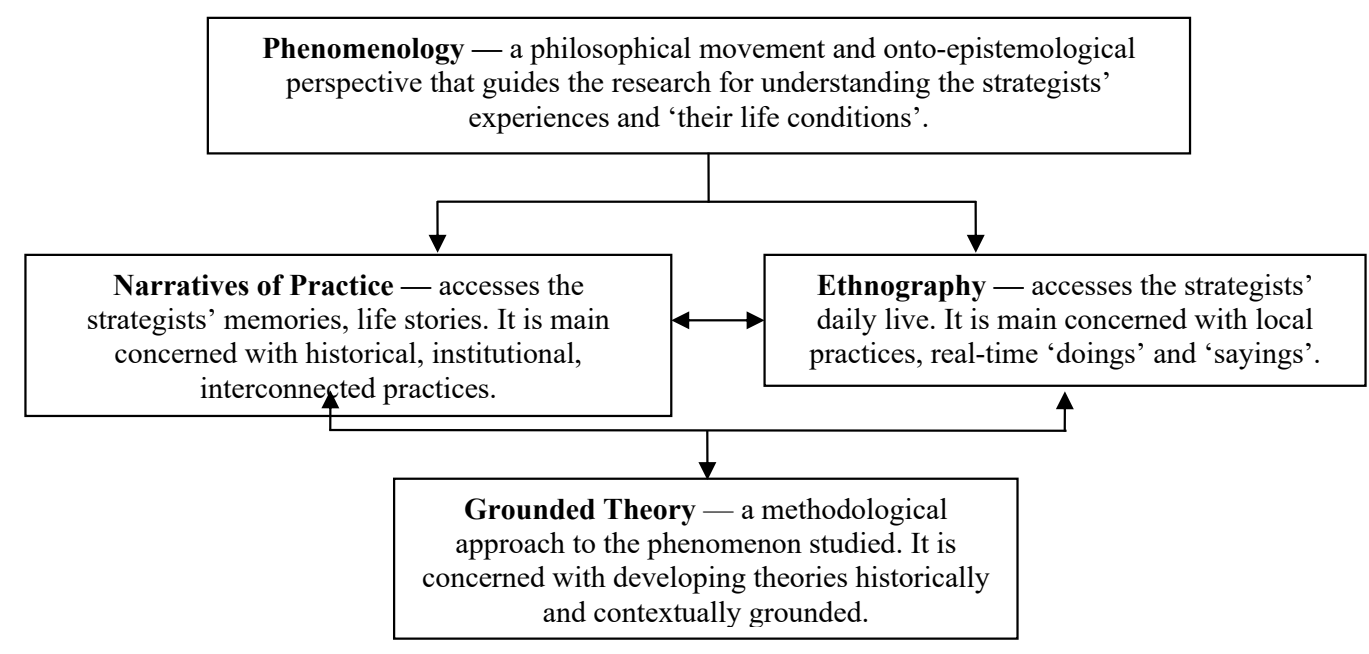

Figure 1. Method design.

Source: prepared by the authors. 
At the top of the Figure 1, there is the interpretative (or existential) Heiddegerian phenomenology. It constitutes the onto-epistemological foundation (Gill, 2014; Orlikowski, 2010; Quay, 2016; Tsoukas, 2010) that should guide the researchers' posture when taking the strategy as practice as its object of research, directing their decisions on what type of data construction and analysis method(s) to use. Instead of orienting themselves by methodological individualism or by societism (Schatzki, 2005), researchers should focus on the dynamic of practice in itself as a starting point for social and strategy-as-practice analysis (Chia, 1995, 2004; Chia \& MacKay, 2007; Reckwitz, 2002; Schatzki, 1996, 2002; Seidl \& Whittington, 2014; Tsoukas, 2010).

Social co-existence is rooted in a field of practices. On the one hand, actors are not acting in isolation but are drawing upon the regular, socially defined modes of acting that arise from the plural social institutions to which they belong. On the other hand, the social infrastructure (tools, technologies, and discourses) through which micro-actions are constructed has macro, institutionalized properties that enable its transmission within and between contexts (Jarzabkowski et al., 2007; Tsoukas, 2010; Vaara \& Whittington, 2012). Connecting "the micro-level more explicitly to the larger picture can now offer a variety of theoretical and practical pay-offs" (Seidl \& Whittington, 2014, p. 1408). For understanding and (re) presenting strategy as practice, we need to see the connection between the here-and-now real-time set of bodily doings and sayings carried out using a variety of tools and the elsewhereand-then other practices embedded in a broader social and historical context (Nicolini, 2009a).

The need to perform these two movements, zoom in (here-and-now) and zoom out (elsewhere-and-then), is what inspires our proposal to use ethnography (Atkinson et al., 2001; Cunliffe, 2010, 2015; Nicolini, 2009a; Rasche \& Chia, 2009) and the practice narratives (De La Ville \& Mounoud, 2010; Fenton \& Langley, 2011; Laslett, 1999; Rouleau, 2010) together. Ethnography and practice narratives appear interconnected in the figure in order to highlight their complementarities as data production empirical methods. Despite recognizing that there are differences between these two approaches, we consider that they also have points in common and can be used together to expand the researcher's possibilities of understanding strategy as practice. Both have conceptual roots on Heiddegerian existential phenomenology and its onto-epistemological assumptions (Gubrium \& Holstein, 1999; Hansen, 2006; Küpers, 2005; Küpers et al., 2013; Vom Lehn \& Hitzler, 2015).

Taken together, they will enable researchers to understand both the conditions of the local real time accomplishment of practice and the ways in which practices are associated into broad textures to form the landscape of practitioners organizational (strategic) life (Nicolini, 2009a;
Feldman \& Orlikowski, 2011; Kouamé \& Langley, 2018). When people tell stories about their own experiences and reflect on the activities they perform in their daily lives, they are influenced by available institutionalized macro-level stories about strategy-making. They tell their stories in ways that reflect or build on expectations created in these macrostories. When these stories are exchanged with other people, "they engender mutual commitments to which subsequent storytelling becomes entrained, generating an ongoing thrust and direction that embeds elements from multiple levels" (Fenton \& Langley, 2011, pp. 1185-1186).

However, it is not a matter of minimizing the importance of close attention to micro-level strategizing praxis. Hence the importance of incorporating the grounded theory that deals with building new substantive theories (transferable to other contexts, not necessarily generalizable) from the actions, behaviors, and words of those who actually live in a specific research context (Bryant, 2017; Charmaz, 2006; Goulding, 2002; Strauss \& Corbin, 1998). Grounded theory, at the bottom of the figure, is considered here as a way of conducting the research work that: (a) guides the 'trips to the field' (for the empirical work of data production) and the 'home visits' (for the analytical effort to understand the empirical data) and; (b) supports the researcher helping to keep the focus on the construction of theoretical contributions beyond the detailed description of the particular case studied (Hendry et al., 2010; Strauss \& Corbin, 1998). What is pointed out is the need to conduct data production and analysis including iterative back and forth loops between data and theory involving categorization and coding of data according to both emerging activity patterns and preexisting theories (Bryant, 2017; Charmaz, 2006; Goulding, 2002). Doing so helps researchers to deal, at the same time, with the challenge of retain sensitivity to local conditions and actors' responses to them and to the social embeddeness and interconnections across levels of analysis (Tsoukas, 2010).

Therefore, we emphasize that a single method is not able to deal with the dynamic, complex, and multiple nature of practices. We need to develop multi-method approaches for appreciating and representing the making of strategy. We should learn to ask to "what extent different methods are sensitive to the nature of practice and what aspects of the practice they are particularly good at articulating and representing" (Nicolini, 2009b, p. 210). The idea to propose a method for strategy as practice scholars is based on the need to offer a "theory-method package 'fit,' in which the methodological tools and their particular configuration are suited to the research question and theoretical aims of the project" (Gehman et al., 2018, p. 297). The design of the presented method increases the accuracy, depth, and richness of the research. Next, we will discuss in detail each approach that constitutes the method. 


\section{PHENOMENOLOGY AND PRACTICAL EXPERIENCE}

There is no such thing as 'the one' phenomenology (Cope, 2005; Gill, 2014; Küpers, 2009; Sandberg \& Dall'Alba, 2009). The term 'phenomenology' involves diverse lines of thought (Gill, 2014) that could have been more adequately brought together in a phenomenological movement (Cope, 2005). Within this movement, at least two main approaches can be highlighted: a descriptive (or transcendental) phenomenology, which has as reference the works of Edmund Husserl (1859-1938), and an interpretative (or existential) phenomenology, inspired mainly by the contributions of Martin Heidegger (18891976). Many of the practice-based approaches that have been used as a reference for the recent developments in strategy as practice research are inspired by this kind of lifeworld perspective (Miettinen, Samra-Fredericks, \& Yanow, 2009; Orlikowski, 2010; Reckwitz, 2002; Sandberg \& Dall'Alba, 2009; Tsoukas, 2010). Therefore, we will focus on this approach to develop our method.

The 'interpretative' (or existential) approach, in a Heideggerian tradition, finds its entry point in the phenomenological movement based on the criticisms it weaves about the foundationalist character of descriptive phenomenology (Gill, 2014; Quay, 2016; Sandberg \& Dall'Alba, 2009; Vom Lehn \& Hitzler, 2015). Rather than seeking to identify pure descriptive categories of the real, the interpretive phenomenologist directs his efforts to describe the meanings constructed by individual being-inthe-world and to understand how these meanings influence the choices that these 'beings' make. More than the study of pure essences, interpretative phenomenology seeks to put essences back into existence - instead of revealing the pure subject, it seeks the incarnated subject, situated in the lifeworld (Conklin, 2012; Gill, 2014; Sandberg \& Dall'Alba, 2009; Sanders, 1982; Van Manen, 1984; Vom Lehn \& Hitzler, 2015).

Heidegger's existential phenomenology shows that the most basic feature of the relation between person and world is not consciousness directed to others and things in the world, as Husserl claimed, but 'being-in-the-world' (Gill, 2014; Heidegger, 1962; Küpers, 2009; Sandberg \& Dall'Alba, 2009). It stipulates that we are inevitably intertwined with our world through constant engagement in specific ways of being-in-the-world, such as cooking, driving, teaching, strategizing (Sandberg \& Dall'Alba, 2009; Schatzki, 2002, 2005). It is our ways of being-in-the-world that enable us to make sense of ourselves, others, and things we use, deal with, and encounter in our everyday activities (Gill, 2014; Sandberg \& Dall'Alba, 2009). From a lifeworld perspective, practices are conceptualized as specific worlds in which members dwell, made up of an array of activities, people, knowledge, equipment, concerns, and so on (Cope, 2005; Reckwitz, 2002; Schatzki, 2002, 2005; Tsoukas, 2010).

As argued by Tsoukas (2010), an onto-epistemological framework inspired by Heideggerian phenomenology enables us to analytically relate strategy making (nondeliberate mode) and strategy practices (deliberate mode) in its various manifestations. It has the potential to help us to take a step forward and overcome the individualist bias that have rightly identified in dominant conceptions of strategy as practice (Chia \& Holt, 2006; Chia \& MacKay, 2007; Sandberg \& Dall'Alba, 2009). This is because, according to Heidegger (1962), this being-in-the-world happens according to two forms of engagement - dwelling and building mode.

The 'building mode' is characterized by the assumptions that individuals are discretely bounded entities and that there is an initial pre-cognitive separation between the actor and the world. Cognition and mental representation of the world necessarily precede any meaningful action and strategic action is explained through recourse to the intention of actors. The strategy actor has first a need to construct mental representations and models of the world prior to any practical engagement with it (Ingold, 2000). Strategizing is thus construed as the act of planning purposeful interventions into the flow of reality to affect a desired outcome (Chia \& Rasche, 2010; Tsoukas, 2010). It is in this 'building mode' that thematic representation, deliberate intention and action take over from everyday coping practices. It is in these moments that we become aware of the symbols and representations that help us retrospectively understand what is happening with the organization (strengths, weaknesses, threats, opportunities), that deliberate and intentional actions come on the scene, and that the various formal activities and strategic episodes (away days, meetings, strategic planning seminars) (Hendry \& Seidl, 2003) take place (Chia \& Holt, 2006; Chia \& Rasche, 2010). It occurs as "a distinctive moment of beingin-the-world that comes about when people step back from immediate practical tasks and reflect on an entity in a detached manner, seeking to identify its properties in abstracto"” (Tsoukas, 2010, p. 59).

In a different way, the 'dwelling mode' does not assume that the identities and characteristics of persons pre-exist social interactions and social practices. People are assumed to be intimately immersed and inextricably intertwined with their surroundings in all their complex interrelatedness. Social practices are given primacy over individual agency and intention. Thus, strategic actions are explained not on the basis of individual intentions but as the product of particular, historically situated practices (Chia \& 
Rasche, 2010; Tsoukas, 2010). The agent acts 'purposively' by drawing on what is directly available from within the specific set of circumstances in which s/he finds her/himself in, to deal effectively with the predicaments and obstacles s/he immediately faces (Miettinen et al., 2009). The strategy emerges not as a result of a previous, conscious mental representation, but as a consequence, a stabilized secondary result of a practical intelligibility incorporated by the practitioner who dwell with the circumstances to which s/he is exposed in a way that can be recognized retrospectively as being strategically consistent (Bouty, Gomez, \& Chia, 2019; Chia \& Holt, 2006; Chia \& MacKay, 2007; Chia \& Rasche, 2010; Tsoukas, 2010).

This Heideggerian phenomenological approach "has important implications for how we view strategy and, crucially, it helps furnish strategy as practice with an ontoepistemology that makes room for different types of action and intentionality" (Tsoukas, 2010, p. 53). This leads us to consider that strategy as practice consists of both: visible and manifest purposeful activities and more mundane everyday practical coping actions. Regnér's (2003) study, for example, shows that we do not have to think of 'building and dwelling' "as mutually exclusive alternatives, but rather like to encourage scholars to use both while making sense of research settings" (Chia \& Rasche, 2010, p. 43). As pointed by Tsoukas (2010), while it is true that the infusion of practitioners with an internalized style of engagement, grounded in culturally transmitted social practices, affords action consistency over time, and thus apparent purposefulness (Bouty et al., 2019; Chia \& Holt, 2006), it is also true that goal-directed actions and reflexive monitoring are not only possible but systemically built into formal organizations (Hendry \& Seidl, 2003; Jarzabkowski \& Seidl, 2008).

\section{THE NARRATIVES OF PRACTICE}

There has been a growing interest on narratives of personal experiences to clarify different organizational research questions, but their full potential has not been explored (Vaara, Sonenshein, \& Boje, 2016). The large number of published papers involving this type of study is a good indicator of its popularity (e.g., Boje, 2001; Czarniawska, 1998; Gabriel, 2000; Küpers et al., 2013; Holstein, Starkey, \& Wright, 2018; Rhodes \& Brown, 2005; Riessman, 1993). In the field of organizational studies, narratives of personal experiences have also gained popularity in the linguistic turn (Alvesson \& Karreman, 2000; Murphy \& O'Brien, 2006) and it is an interesting means through which researchers can understand actors' experiences in organizations (Humphries \& Smith, 2014). Through narratives, people share and disseminate their perceptions on their work and the processes in which they engage (Patriotta, 2003). They are storytellers and their stories are valuable empirical data (Rhodes \& Brown, 2005).

Organizational narratives can be defined as "temporal, discursive constructions that provide a means for individual, social and organizational sensemaking and sensegiving" (Vaara, Sonenshein, \& Boje, 2016, p. 3). Therefore, studies employing the narrative approach focus on stories. These stories aim to return to the individual moment to describe when and how the individual experienced certain phenomena (Adorisio, 2014). It has the potential to reveal different perspectives and feelings of organizational members (Boje, Rosile, Saylors, \& Saylors, 2015). Narratives should be a privileged method for capturing the ordinary and daily character of organizing (Patriotta, 2003). It offers a methodological way and a different form of knowledge for researchers to engage with everyday organizational life (Rhodes \& Brown, 2005).

Strategists are assumed to be able to supply varied life experiences to improve understanding on how strategizing develops over time (Rouleau, 2006), activating the past through narratives (Adorisio, 2014). Strategy is constituted by "working and re-working through narrative of past, present, and future" (Holstein et al., 2018, p. 78). When narrating their strategizing stories practitioners: (a) reveal their work life conditions, (b) make explicit their doings and saying, (c) describe the characters with whom they interacted and the activities in which they participated, and (d) talk about the tools/artifacts that they used while they strategized (Denis, Langley, \& Rouleau, 2007).

Contrary to how this method may appear, it is not necessarily limited to the micro-level of analysis (see Boje, Haley, \& Saylors, 2016). The narratives of practice, as Bertaux (1980) shows, incorporate diverse contextual elements. Upon recounting their stories, individuals refer to details that cut across different levels of analysis (Vaara et al., 2016). The life stories share a social dimension that enables us to analyze not only an individual but also a social object that acts as a fragment of a socio-historic reality (Laslett, 1999). Therefore, we should augment the narrative interpretation by employing a research design that allows intimate analysis of the narrative's context (Hansen, 2006).

In this sense, undertaking an ethnographic effort to add insight to the text and language would be interesting (see Kalou \& Sadler-Smith, 2015). If speech is a fundamental element of culture and practice, then the discursive elements are not the only ingredients utilized to build meaning and give form to actions (Barry, Carroll, \& Hansen, 2006; Schatzki, 2002). There is always a context in which an individual's understandings are ordered and put into practice (Hansen, 2006; Schatzki, 2002). Soin and Scheytt (2006), for example, argued that narratives should not be taken as single sources of empirical data. Rather, they should 
be analyzed together with ethnographic methods. Gubrium and Holstein (1999) stated that ethnography would allow researchers to perceive the hidden details of living that do not appear in narratives.

\section{ETHNOGRAPHY AND PRACTICE}

Overall, ethnography is the description of a culture. It enables the understanding of others and their daily social lives (see Atkinson et al., 2001; Bernard \& Gravlee, 2015). To accomplish these goals, the researcher lives intensely and for long periods in the environment of the study population (Cunliffe, 2010; Van Manen, 1984). This increases the validity of the strategy as practice studies as these practices "reflect the reality of the life experiences of participants more accurately than do contrived settings" (LeCompte \& Goetz, 1982, p. 43). In this way, the researcher understands the mechanisms of social processes, their structure and functioning, and how such processes, structure, and actors are involved (Rosen, 1991).

The ethnographic encounter gives the researcher a unique opportunity to see the reality of a group of people (Kalou \& Sadler-Smith, 2015) in their natural setting (Goulding, 2005). In addition to studying the people, the researcher learns from them and describes their realities in the respondents' own terms (Cunliffe \& Karunanayake, 2013; Spradley, 1979). The researcher must always have an additional understanding and knowledge of the reality of the study population, rather than only academically predefined categories (Cunliffe, 2010). The ethnographic description must be undertaken from experiences within the analyzed context because the events that occur can only be understood in the context of their production (Hammersley, 1992).

Rasche and Chia (2009) asserted that though some researches have employed the ethnographic perspective (Jarzabkowski \& Wilson, 2002; Samra-Fredericks, 2003), few have effectively used participant observation as a fundamental element for the study of SAP. Using the ethnographic method, the researcher would live with strategists, learn their language, and participate in their practices and rituals (Vesa \& Vaara, 2014). Researchers would observe their daily situations and activities in different scenarios and at different levels. The researchers could use systemic observation to understanding strategizing's nonformalized aspects: "the everyday problem-solving, the opportunistic making-do's and the ingenuity and guile displayed at every level in the organization" (Rasche \& Chia, 2009, p. 726).

Although ethnographers have made considerable efforts to produce detailed descriptions, little has been performed to develop concepts to support a robust theoretical structure (Fine, 2003; Lofland, 1995) and many ethnographic studies have simply led to an endless number of dispersed data islands (Prus, 1987). In general, the task of developing theories is either ignored or treated as a 'black box' (Snow, Morrill, \& Anderson, 2003). The 'black box' is related to an 'intermediary moment' between what Van Maanen (1988) called the first (data collection) and the second (production of ethnographic text) moments of ethnographic research. That 'intermediate moment' in which data analysis occurs is normally left aside.

Copious material has been written about different aspects related to the first and second moments. Authors have detailed methods to negotiate access to the field (Cunliffe \& Alcadipani, 2016), to establish and maintain relations with the study population (Rosen, 1991), to write a diary (Emerson, Fretz, \& Shaw, 1995), and to decide when to leave the field (Iversen, 2009). However, little has been published regarding data analysis and about the methods by which the researcher transforms their raw data into the final narrative in an intermediate moment (Snow et al., 2003). So, ethnography may be combined with other research methods (Watson, 2011), such as grounded theory, to improve its analytical dimension (Charmaz \& Mitchell, 2001).

\section{THE CHOICE OF A GROUNDED THEORY}

We advocate for finding a research approach that transcends simple description of strategist activities. Grounded theory has the necessary tools to achieve this goal insofar it is theory building (Goulding, 2017) and explanations emerge from the field (Walsh et al., 2015). As stressed by Charmaz and Mitchell (2001), ethnographic studies usually have the problem of presenting lists of unintegrated categories. Using grounded theory can give researchers a more complete view of the phenomena and guide researcher toward theoretical interpretation, assisting the ethnographer in structuring and organizing the data (Charmaz \& Mitchell, 2001). Instead of simply focus on the thick descriptions, grounded theory involves building strong concepts and categories (Bryant, 2017) that should not only offer descriptions but also explanations (Corbin \& Strauss, 1990).

In this approach, theory must be directly related to the participants' lives, experiences, and practices (Corley, 2015; Mills, Bonner, \& Francis, 2006). It is necessary to maintain a clear and direct connection with the data, but the theory should not be limited to a simple description of stories (Goulding, 1998). Though grounded theory has supporters as a result of its assumptions and phenomenological techniques, its focus is not on individuals' subjective experience per se. Grounded theorists attempt to reach a 
slightly higher level of abstraction, higher than the data itself (Suddaby, 2006).

Constructing a grounded theory involves continuity between theoretical and empirical levels (Bryant, 2017; Corbin \& Strauss, 1990; Goulding, 2005). The theory is developed during the research process and emerges as a product of the continual interaction between analysis and data collection (Goulding, 2002). As such, data and theories are produced, similar to interpretive grounded theory, initially suggested by Strauss and Corbin (1998), and constructive grounded theory, developed by Charmaz (2006). Mintzberg (1979) has already suggested that "there is no one-to-one correspondence between data and theory." (Mintzberg 1979, p. 582). Data does not generate theory. Only researchers do so. As Goulding has stated, "researcher reflexivity should be an integral part of the process, as should work on the social construction of the world under the study" (Goulding, 2017, p. 64).

One of the main strengths of grounded theory is that its flexible set of analytical strategies can be used as the researcher wishes (Charmaz, 2000; Corley, 2015). The grounded theory guidelines should be used as "a general way of generating theory" (Atkinson et al., 2001, p. 150) grounded in data (Goulding, 2017). Adopting a grounded theory approach aids in sorting through the richness of the data obtained from narratives and ethnography in a systematic and integrated way. Thus, researchers can extend the analytical frontiers and theoretical sophistication of their fieldwork. Grounded theory approach allows researchers better access to the context and the study population (Corbin \& Strauss, 1990) such that researchers can better understand experiences (Bryant, 2017).

\section{DISCUSSION AND METHODOLOGICAL IMPLICATIONS}

A broad implication of the proposed method is that its design helps to capture life conditions and understand human activities in the theory of practice, going beyond a specific focus on aspects of micro- or macro-strategizing. So, this approach implies that a relational philosophy should be adopted, directing researchers' attention more to the process - the organizing - and less to the thing - the organization (Shepherd \& Suddaby, 2017). That is, relationships should occupy a central position in analyses (Chia, 2003). In this sense, by starting from phenomenology approach it is possible to study actors in their own environment (Van Manen, 1984), analyzing the context of their lively experiences (Vom Lehn \& Hitzler, 2015).

The proposed method has phenomenology as basic assumption because from it we can apprehend the lived experiences of individuals in their daily activities and "for organization researchers, much of the potential scope and value of phenomenology remains unrealized" (Gill, 2014, p. 119). Studying strategizing through phenomenological approach enables researches to understand how knowledge emerges through our engagement with the world (Willems, 2018). SAP research offers an interesting area to apply the phenomenological assumptions combined with narrative. Besides the growth of narrative studies on strategy as practice (Vaara et al., 2016), organizational strategy is increasingly flexible. As Küpers, Mantere, and Statler (2013) argue, to be open to emerging change is one of the main characteristics of phenomenology that recognize narratives as a basic aspect of lifeworld.

An interpretative phenomenology views all human experience as intrinsically narrative, emphasizes the way in which narrative experiences are always embodied in a context that involves an interplay of people, cultures, environments, and objects (Cunliffe, Luhmann, \& Boje, 2004; Küpers, 2005). This approach can bring researcher closer to practitioners (Küpers et al., 2013) and enable a better understand of day-to-day strategists. Narrative can be found in the micro-stories told by managers and others as they interact and go about their daily work and in the accounts that people give of their work as strategy practitioners (De La Ville \& Mounoud, 2010). This is a method that provides broad and deep data collection: data based on a temporal schema, data embedded in a context, data that can be compared, data that can be gathered from individuals belonging to all hierarchical levels, allowing collection of a wide range of empirical evidence (practices, events, discourses, representations, artifacts, tools, object) (Rouleau, 2010).

Considering that narrative is central to phenomenological approach (Küpers et al., 2013), to employ it would access to the practitioners' storytelling that gives sense to their organizational life (Rhodes \& Brown, 2005) and their identity as strategists (Mantere \& Whittington, 2020). Narratives contribute to a better understanding of how strategy-making involves sensemaking and sensegiving (Vaara et al., 2016). So, the proposed method is useful to investigate, for instance, the underlying assumptions of a strategy narrative and how conflict between competing narratives is resolved (see Rhodes \& Brown, 2005; Boje et al., 2016; Holstein et al., 2018). Researchers should interview the various actors involved in strategizing to trace their narratives (Czarniawska, 1998). As asserted by Küpers et al. (2013), "from a phenomenological perspective, narratives are a mode of human existence" (Küpers et al., 2013, p. 86) and "the power of stories lies in their capacity to encompass thinking and feeling about issues and thereby to compel people to take certain actions and avoid others" (Küpers et al., 2013, p. 96). 
However, despite the importance of the lived experience of the practitioners, a central issue for strategizing research is its attempt to overcome micro/macro dichotomy existing in strategy literature (Chia \& MacKay, 2007). Whittington (2011) states that practices approach have been limited to investigate individual activities of actors, while they should embrace both analysis levels (micro and macro), even if one or the other does not appear clearly in a given time (Whittington, 2011). Accordingly, we should go beyond everyday interactions analysis and try to understand how praxis may influence and be influenced by organizational and institutional level practices and explain the role of practitioner in strategizing.

Watson and Watson (2012) highlight that the holistic character of ethnography and its concern about culture can contribute to dealing with the different levels that encompass the social world. If on the one hand, the studies using narratives approach primarily collected stories through interviews in a planned conversation for that aim, on the other hand, observation of in vivo practitioners' interactions enables researchers to evidence the ongoing narratives (Fenton \& Langley, 2011) and how they are embedded in praxispractices-practitioners (Whittington, 2006). Ethnography significantly enhances the immersion of researcher into fieldwork (Eisenhardt, Graebner, \& Sonenshein, 2016; Rosen, 1991), enabling the collection of a great amount of date. Thus, it is not necessary for the researcher to maintain distance from the object of the study (Whittington, 2004). Thereby, ethnography seems to be a powerful method to study social/cultural aspects surrounding strategizing and provide depth descriptions of connections between different levels of analysis (see Jarzabkowski, Bednarek, \& Cabantous, 2014).

For example, an advantage of using ethnography in SAP studies is its potential to allow researchers to observe informal and natural interactions between practitioners. It facilitates access to the organization's artifacts and documents, as well as helping to observe strategy toolmaking process (see Burkea \& Wolf, 2020). This provides insights into the macro-level of the organizational context as these elements are employed to materialize cultural and institutional characteristics of the external environment such as shared norms, values, and meanings. At the same time, the ethnographic method sheds light on the microlevel of strategizing by allowing researchers to investigate the "'behind the scenes' work and follow its consequences for the unfolding dynamics of changes to strategy arrangements" (Whittle, Gilchrist, Mueller, \& Lenney, 2020, p. 4). The backstage can be accessed by a systematic observation and actors' narratives (see Whittle et al., 2020). Narratives can be used to capture the actors' stories about how they manipulate these strategic artifacts in their organizational daily lives. Doing so, the researcher would be able to access actors' personal experiences (Adorisio, 2014) of strategizing.

Aiming at study strategy teams under strategy as practice perspective, Paroutis and Pettigrew (2007) employ the case study as method research and collected data through interviews and documents. The authors, however, knew that "an ethnographic approach might have provided more detailed accounts of the actual activities used by strategy teams" (Paroutis \& Pettigrew, 2007, p. 107). Cunliffe (2015) argues that ethnography is particularly suited to SAP research because of its focus on the rich description of the micro-practices of organizational life. This is a direct result of the nature of the phenomenon itself: dynamic, complex, involving intense human interaction and the need to get close to the phenomenon (Rasche \& Chia, 2009).

At this point, it is worth addressing the validity criterion of ethnography studies. As highlighted by LeCompte and Goetz (1982), researchers should be attentive to observer effects, that is, the presence of the researcher in the fieldwork. According to these authors, researchers can handle this problem by establishing several field relationships (e.g., create rapport with practitioners from different hierarchical levels), searching for independent corroboration of the data collected (e.g., observe and interview actors with different points of view on strategizing), and including their field position in the final report. Doing so, researchers can control possible distortion in the data (LeCompte \& Goetz, 1982).

Although ethnography is a strong method to understand ongoing practices and their contexts, it has some limitations that could be overcome by some grounded theory assumptions. One of these limitations is its inability to theoretical development. According to Snow, Morrill, and Anderson (2003), it is important to consider some pathways to theoretical development, like dealing more systematically with data analysis and emerging categories. The grounded theory has potential to contribute to the ethnography, completing it 'intermediary moment' in which data analysis occurs. So, the problem of rigid separation of data collection and analysis would be solved by comparing data with data (and with emerging categories) from the beginning (Alammar, Intezari, Cardow, \& Pauleen, 2019), not after the data gathering is finished, and demonstrating concepts and categories relations (Charmaz \& Mitchell, 2001). A systematic approach is needed to link field data to building theories (Bryant, 2017) and challenge assumptions underlying existing theories (Alvesson \& Sandberg, 2011). All these characteristics of grounded theory can formalize and improve the narrow theoretical aspect of ethnography (Pettigrew, 2000).

The combination of ethnography and grounded theory should follow in a similar way Pettigrew's (2000) indication: researcher uses ethnography methods to 
collect data and analyze the fieldwork materials according to the principles of the grounded theory, producing thick description and theoretical account of strategizing. We can add to this indication the use of theoretical sampling (Glaser \& Strauss, 2006) as a strategy to enhance the validity of the study, assuring that adequate informants and interviewees are being chosen in order to represent the analyzed population (LeCompte \& Goetz, 1982). Thereby, it is possible to describe in detail praxis-practicespractitioners through narratives and understand the multiple levels (individual, organizational, and societal) in which strategizing occurs. This combination allows building strong theories with "well-defined concepts, relationships between constructs, and underlying logical arguments that support these relationships" (Eisenhardt et al., 2016, p. 1120).

\section{FUTURE RESEARCH DIRECTIONS}

The proposed method is primarily inductive in its approach, so it is "particularly appropriate in new or understudied empirical contexts where there is relatively little prior work" (Bansal, Smith, \& Vaara 2018, p. 1190), enabling SAP scholars to offer new theoretical directions. This is especially relevant in contexts where strategists are facing wicked problems in their organizational activities (Burkea \& Wolf, 2020). In this sense, more specifically, the method may be useful for studying two underexplored topics in the SAP literature: (a) strategic changing in pluralistic context/organizations (Denis et al., 2007; Jarzabkowski \& Fenton, 2006; Sorsa \& Vaara, 2020) and (b) open strategy (Hautz, Seidl, \& Whittington, 2017; Mantere \& Whittington, 2020; Whittington, Cailluet, \& Yakis-Douglas, 2011).

Much strategy theory is inadequate to studystrategizing in pluralistic contexts (Jarzabkowski \& Fenton, 2006) and social practice theoretical frames can deal with that particularity (Denis et al., 2007). Pluralistic contexts "are those that are shaped by the divergent goals and interests of different groups inside and outside the organization" (Jarzabkowski \& Fenton, 2006, p. 631). Although Denis et al., (2007) present some theoretical frames to study strategizing in pluralistic contexts, they do not make clear and do not detail statements about methodological issues. So, our proposed method contributes to fill this gap. As we discussed earlier, our proposed method enables researcher to apprehend multiple levels of analysis, making possible for the researcher to understand the divergent goals, in a way that inside and outside interests are identify by storytelling of practitioners, observed in vivo praxis and the relations between actors, so connecting with societal practices of a specific context.
By investigating actors' narratives of a Nordic city organization, Sorsa and Vaara (2020) found out four rhetorical practices used to promote strategists' own interest and values during organizational strategic changes. The study link field data to theory (Bryant, 2017), providing an empirical grounded representation of how rhetorical strategy works. However, as a limitation the authors pointed out that Nordic cultural context may have influenced the findings. Without consider the broader context such as local institutions, sector practices, and public discourses which are also relevant for strategy as practice (Hautz et al., 2017; Suddaby et al., 2013), their analysis did not focus on the macro-level. An ethnography approach could fill this gap since it allows researchers to add insights to the text (Kalou \& Sadler-Smith, 2015) emerged from interviews and documents as well as highlight the narrative's context (Hansen, 2006) where stories about strategizing are told and practitioners' actions are performed. To offer a consistent explanation and theoretical interpretations beyond thick descriptions, researchers should use grounded theory to support the process of structuring and organizing the data (Charmaz \& Mitchell, 2001).

Secondly, Whittington, Cailluet and Yakis-Douglas (2011) identify that strategy has become more 'open.' The concept of open strategy is characterized by "an openness in terms of inclusiveness, in other words the range of people involved in making strategy; and an openness in terms of transparency, both in the strategy formulation stage and, more commonly, in the communication of strategies" (Whittington, et al., 2011, p. 532). The authors highlight four forces that foster openness in strategy work (societal, organizational, cultural, and technological), which will become more mundane and spread throughout the organization. Thus, openness is both macro- and microphenomena once strategizing is seen as a local set of activities that have widely repercussion in society and are influenced by new information technology, the rise of knowledge work, and collaborative economy (Hautz et al., 2017).

The proposed method could be used to investigate how potential new 'practices' shape the daily activities (praxis) of 'practitioners' while these actors are strategizing in an open and transparent organization. This movement requires analyzing the practitioners' narratives and at the same time observing their (inter)actions through an ethnographic-based study to describe strategic aspects influenced by cultural and institutional dimensions. To overcome the risk of being just a descriptive research, losing the opportunity to theorize about a new phenomenon, grounded theory offers the appropriate tools to move from concrete data to the conceptual level (Alammar et al., 2019), which provides an explanation of the characteristics and implications of the open strategy for strategizing. Hautz, Seidl, and Whittington (2017) claim that "Open 
Strategy can thus contribute to the melding of micro- and macro-approaches in Strategy-as-Practice research" because it allows to capture the broader demands of strategy practice and understand local organizational problems (Hautz et al., 2017, p. 299).

Finally, we would like to advise that the proposed method is not a rigid path to do qualitative research on strategy as practice, but it should be adapted according to the main focus of the study. As highlighted by Gehman et al. (2018), "every qualitative theory-method package, while potentially providing some degree of template or exemplar, nonetheless needs to be customized for a particular research context" (Gehman et al., 2018, p. 297) since researchers have to be sensitive to the interplay between theory and method (Van Maanen, Sørensen, \& Mitchell, 2007).

\section{CONCLUSION}

The aim of this paper was to discuss potential methods to guide empirical studies of strategy as practice (SAP). Drawing on phenomenology, narratives, grounded theory, and ethnography, the method design is an endeavor to combine multiple qualitative research approaches to provide a starting point for scholars interested in understanding the complex world of strategizing. The method presented in this paper offers two main implications for the literature on strategizing. First, the research method helps avoiding

\section{REFERENCES}

Adorisio, A. L. M. (2014). Organizational remembering as narrative: 'Storying' the past in banking. Organization, 21(4), 463476. https://doi.org/10.1177/1350508414527248

Alammar, F. M., Interazi, A., Cardow, A., \& Pauleen, D. J. (2019). Grounded theory in practice: novice researchers' choice between Straussian and Glaserian. Journal of Management Inquiry, 28(2) 228-245. https://doi.org/10.1177/1056492618770743

Alvesson, M., \& Karreman, D. (2000). Taking the linguistic turn in organizational research: challenges, responses and consequences. Journal of Applied Behavioral Science, 36(2), 136-159. https://doi.org/10.1177/0021886300362002

Alvesson, M., \& Sandberg, J. (2011). Generating research questions through problematization. Academy of Management Review, 36(2), 247-271. https://doi.org/10.5465/amr.2009.0188

Atkinson, P., Coffey, A., Delamont, S., Lofland, J., \& Lofland, L. (2001). Editorial introduction. In P. Atkinson, A. Coffey, S. Delamont, J. Lofland, \& L. Lofland (Eds.), Handbook of ethnography (pp. 1-7). London: Sage Publications. the dichotomy between macro- and micro-levels of analysis in the study of strategy as practice. Second, we also offer a methodological lens that allows researchers to integrate the praxis, practice, and practitioner dimensions, which is something that SAP scholars have been pointing out as a challenge to be overcome.

However, applying our method to guide empirical studies of SAP is not without limitations. Due to its complexity and to a demand for a relatively large amount of data that needs to be collected in the research field, this approach requires a long period of data collection. As many researchers have short deadlines for their projects, time is an aspect that needs to be evaluated before our method can be put into practice. Also, the researcher needs to have a broad access to the research field of interest. As access usually requires time, achieving both simultaneously can be a hard task in some situations.

The research approach presented in this study is not free from challenges. First, it is necessary to carefully construct a research plan, so that both limitations that were indicated in the last paragraph can be overcome. Second, it is also important that the researcher can be able to create a satisfactory connection between both micro- and macrolevels of analysis, without underemphasizing one of them. This is a hard challenge to overcome, as in some cases researchers can feel 'seduced' by the stories that are told by the subjects in the micro-level or by the social structures under which such stories take place.

Balogun, J., Huff, A. S., \& Johnson, P. (2003). Three responses to the methodological challenges of studying strategizing. Journal of Management Studies, 40(1), 197-224. https://doi.org/10.1111/1467-6486.t01-1-00009

Bansal, P., Smith, W. K., \& Vaara, E. (2018). From the editors: New ways of seeing through qualitative research. Academy of Management Journal, 61(4), 1189-1195. https://doi.org/10.5465/amj.2018.4004

Barry, E., Carroll, B., \& Hansen, H. (2006). To text or context? Endotextual, exotextual and multi-textual approaches to narrative and discursive organizational studies. Organization Studies, 27(8), 1091-1110. https://doi.org/10.1177/0170840606064568

Bernard, H. R., \& Gravlee, C. C. (2015). Handbook of methods in cultural anthropology. London: Rowman \& Littlefield.

Bertaux, D. (1980). L'approche biographique: sa validité méthodologique, ses potentialités. Cahiers Internationaux de Sociologie, 69, 197-225. 
Boje, D. M. (2001). Narrative methods for organizational and communication research. London: Sage Publications.

Boje, D. M., Haley, U. C. V., \& Saylors, R. (2016). Antenarratives of organizational change: the microstoria of Burger King's storytelling in space, time and strategic context. Human Relations, 69(2), 391-418. https://doi.org/10.1177/0018726715585812

Boje, D. M., Rosile, G. A., Saylors, J., \& Saylors, R. (2015). Using storytelling theatrics for leadership training. Advances in Developing Human Resources, 17(3), 348-362. https://doi.org/10.1177/1523422315587899

Bouty, I., Gomez, M. L., \& Chia, R. (2019). Strategy emergence as wayfinding. M@n@gement, 22(3), 438465. Retrieved from https://search.proquest.com/ openview/fa2a $8425902 \mathrm{a} 5624 \mathrm{f} 18 \mathrm{ca} 121 \mathrm{~d} 2 \mathrm{f} 228 \mathrm{ed} / 1$ ? pq-origsite $=$ gscholar $\& \mathrm{cbl}=286201 \#:-:$ text $=\mathrm{We} \% 20$ thus $\% 20$ contribute $\% 20$ to $\% 20$ strategy,unexpectedly $\% 20$ produce $\% 20 \mathrm{a} \% 20$ coherent $\% 20$ strategy.

Bryant, A. (2017). Grounded theory and grounded theorizing: Pragmatism in research practice. New York: Oxford University Press.

Burkea, G. T., \& Wolf, C. (2020). The process affordances of strategy toolmaking when addressing wicked problems. Journal of Management Studies, online first, 1-30. https://doi.org/10.1111/joms.12572

Charmaz, K. (2000). Constructivist and objectivist grounded theory. In N. K. Denzin, \& Y. S. Lincoln, (Eds.), Handbook of qualitative research (pp. 397-412). Thousand Oaks: Sage Publications.

Charmaz, K. (2006). Constructing grounded theory: A practical guide through qualitative analysis. London: Sage Publications.

Charmaz, K., \& Mitchell, R. G. (2001). Grounded theory in ethnography. In P. Atkinson, A. Coffey, S. Delamont, J. Lofland, \& L. Lofland (Eds.), Handbook of ethnography (pp. 160-174). London: Sage Publications.

Chia, R. (1995). From modern to postmodern organizational analysis. Organizational Studies, 16(4), 579-604. https://doi.org/10.1177/017084069501600406

Chia, R. (2003). Ontology: Organization as "world-making". In R. Westwood, \& S. Clegg, (Org.). Debating organization: Point-counterpoint in organization studies. (pp. 98-112). Oxford: Blackwell.

Chia, R. (2004). Strategy-as-practice: reflections on the research agenda. European Management Review, 1(1), 29-34. https://doi.org/10.1057/palgrave.emr.1500012

Chia, R., \& Holt, R. (2006). Strategy as practical coping: A Heideggerian perspective. Organization Studies, 27(5), 635-655. https://doi.org/10.1177/0170840606064102

Chia, R., \& MacKay, B. (2007). Post-processual challenges for the emerging strategy-as-practice perpsective: Discovering strategy in the logic of practice. Human Relations, 60(1), 217-242. https://doi.org/10.1177/0018726707075291
Chia, R., \& Rasche, A. (2010). Epistemological alternatives for researching strategy as practice: building and dwelling worldviews. In D. Golsorkhi, L. Rouleau, D. Seidl, \& Vaara, E. (Eds), Cambridge handbook of strategy as practice (pp. 34-46). Cambridge: Cambridge University Press.

Conklin, T. (2012). Work worth doing: A phenomenological study of the experience of discovering and following one's calling. Journal of Management Inquiry, 21(3), 298-317. https://doi.org/10.1177/1056492611414426

Cope, J. (2005). Researching entrepreneurship through phenomenological inquiry: philosophical and methodological issues. International Small Business Journal, 23(2), 163-189. https://doi.org/10.1177/0266242605050511

Corbin, J., \& Strauss, A. (1990). Grounded theory research: procedures, canons, and evaluative criteria. Qualitative Sociology, 13(1), 3-21. Retrieved from https://link.springer.com/article/10.1007/BF00988593

Corley, K. G. (2015). A commentary on "what grounded theory is...": Engaging a phenomenon from the perspective of those living it. Organizational Research Methods, 18(4), 600-605. https://doi.org/10.1177/1094428115574747

Cunliffe, A. L. (2010). Retelling tales of the field in search of organizational ethnography 20 years on. Organizational Research Methods, 13(2), 224-239. https://doi.org/10.1177/1094428109340041

Cunliffe, A. (2015). Using ethnography in strategy-as-practice research. In D. Golsorkhi, L. Rouleau, D. Seidl, \& E. Vaara (Eds.), Cambridge handbook of strategy as practice (pp. 431-446). Cambridge: Cambridge University Press.

Cunliffe, A. L., \& Alcadipani, R. (2016). The politics of access in fieldwork: Immersion, backstage dramas, and deception. Organizational Research Methods, 19(4), 535-561. https://doi.org/10.1177/1094428116639134

Cunliffe, A. L., \& Karunanayake, G. (2013). Working within hyphen-spaces in ethnographic research: Implications for research identities and practice. Organizational Research Methods, 16(3), 364-392. https://doi.org/10.1177/1094428113489353

Cunliffe, A. L., Luhmann, J. T., \& Boje, D. (2004). Narrative temporality: implications for organizational research. Organization Studies, 25(2), 261-286. https://doi.org/10.1177/0170840604040038

Czarniawska, B. (1998). A narrative approach to organization studies. London: Sage Publications.

De La Ville, V. I., \& Mounoud, E. (2010). A narrative approach to strategy as practice: Strategy making from texts and narratives. In D. Golsorkhi, L. Rouleau, D. Seidl, \& E. Vaara (Eds.), Cambridge handbook of strategy as practice (pp. 183-197). Cambridge: Cambridge University Press.

Denis, J. L., Langley, A., \& Rouleau, L. (2007). Studying strategizing in pluralistic contexts: rethinking theoretical frames. Human Relation, 60(1), 179-215. https://doi.org/10.1177/0018726707075288 
Eisenhardt, K. M., Graebner, M. E., \& Sonenshein, S. (2016). Grand challenges and inductive methods: rigor without rigor mortis. Academy of Management Journal, 59(4), 1113-1123. https://doi.org/10.5465/amj.2016.4004

Emerson, R. M., Fretz, R. I., \& Shaw, L. L. (1995). Writing ethnographic fieldnotes. Chicago: University of Chicago Press.

Feldman, M. S., \& Orlikowski, W. J. (2011). Theorizing practice and practicing theory. Organization Science, 22(5), 1240 1253. https://doi.org/10.1287/orsc. 1100.0612

Felix, B., Mello, A., \& von Borell, D. (2018). Voices unspoken? Understanding how gay employees co-construct a climate of voice/silence in organisations. The International Journal of Human Resource Management, 29(5), 805-828. https://doi.org/10.1080/09585192.2016.1255987

Fenton, C., \& Langley, A. (2011). Strategy as practice and the narrative turn. Organization studies, 32(9), 1171-1196. https://doi.org/10.1177/0170840611410838

Fine, G. A. (2003). Towards a peopled ethnography: Developing theory from group life. Ethnography, 4(1), 41-60. https://doi.org/10.1177/1466138103004001003

Fook,J.(2002). Theorizingfrompracticetowardsaninclusiveapproach for social work research. Qualitative Social Work, 1(1), 7995. https://doi.org/10.1177/147332500200100106

Gabriel, Y. (2000), Storytelling in organizations: facts, fictions and fantasies, Sage Publications, London.

Gehman, J., Glaser, V. L., Eisenhardt, K. M., Gioia, D., Langley, A., \& Corley, K. G. (2018). Finding theory-method fit: a comparison of three qualitative approaches to theory building. Journal of Management Inquiry, 27(3), 284-300. https://doi.org/10.1177/1056492617706029

Gherardi, S. (2009). Introduction: The critical power of the practice lens. Management Learning, 40(2), 115-128. https://doi.org/10.1177/1350507608101225

Gill, M. J. (2014). The possibilities of phenomenology for organizational research. Organizational Research Methods, 17(2), 118-137. https://doi.org/10.1177/1094428113518348

Glaser, B. G., \& Strauss, A. (2006). The discovery of grounded theory: Strategy for qualitative research. New Burnswick, London: Aldine.

Golsorkhi, D., Rouleau, L., Seidl, D., \& Vaara, E. (2010). Introduction: What is Strategy as Practice? In D. Golsorkhi, L. Rouleau, D. Seidl, \& E. Vaara. (Eds.). Cambridge Handbook of Strategy as Practice. (pp. 1-20). Cambridge: Cambridge University Press.

Goulding, C. (1998). Grounded theory: The missing methodology on the interpretivist agenda. Qualitative Market Research, 1(1), 50-57. https://doi.org/10.1108/13522759810197587

Goulding, C. (2002). Grounded theory: A practical guide for management, business and market researchers. London: Sage Publications.
Goulding, C. (2005). Grounded theory, ethnography and phenomenology: A comparative analysis of three qualitative strategies for marketing research. European Journal of Marketing 39(3-4), 294-308. https://doi.org/10.1108/03090560510581782

Goulding, C. (2017). Navigating the complexities of grounded theory research in advertising. Journal of Advertising, 46(1), 6170. https://doi.org/10.1080/00913367.2017.1281775

Gubrium, J. F., \& Holstein, J. A. (1999). At the border of narrative and ethnography. Journal of Contemporary Ethnography, 28(5), 561-573. https://doi.org/10.1177/089124199129023550

Hammersley, M. (1992). What's wrong with ethnography. New York: Routledge.

Hansen, H. (2006). The ethnonarrative approach. Human Relations, 59(8), 1049-1075. https://doi.org/10.1177/0018726706068770

Hautz, J., Seidl, D., \& Whittington, R. (2017). Open strategy: Dimensions, dilemmas, dynamics. Long Range Planning, 50(3), 298-309. https://doi.org/10.1016/j.lrp.2016.12.001

Heidegger, M. (1962). Being and time. New York: Harper and Row.

Hendry, J., \& Seidl, D. (2003). The structure and significance of strategic episodes: Social systems theory and the routine practices of strategic change. Journal of Management Studies, 40(1), 175-196. https://doi.org/10.1111/1467-6486.00008

Hendry, K. P., Kiel, G. C., \& Nicholson, G. (2010). How boards strategise: A strategy as practice view. Long Range Planning, 43(1), 33-56. https://doi.org/10.1016/j.lrp.2009.09.005

Holstein, J., Starkey, K., \& Wright, M. (2018). Strategy and narrative in higher education. Strategic Organization, 16(1), 61-91. https://doi.org/10.1177/1476127016674877

Humphries, C., \& Smith, A. C. T. (2014). Talking objects: Towards a postsocial research framework for exploring object narratives. Organization, 21(4), 477-494. https://doi.org/10.1177/1350508414527253

Hydle, K. M. (2015). Temporal and spatial dimensions of strategizing. Organization Studies, 36(5), 643-663. https://doi.org/10.1177/0170840615571957

Ingold, T. (2000). The perception of the environment. New York: Routledge.

Iszatt-White, M. (2010). Strategic leadership: The accomplishment of strategy as a 'perennially unfinished. Leadership, 6(4), 409-424. https://doi.org/10.1177/1742715010379310

Iversen, R. R. (2009). Getting out in ethnography: A seldomtold story. Qualitative Social Work, 8(1), 9-26. https://doi.org/10.1177/1473325008100423

Jarzabkowski, P. (2005). Strategy as Practice: an activity-based approach. London: Sage Publications.

Jarzabkowski, P., \& Fenton, E. (2006). Strategizing and organizing in pluralistic contexts. Long Range Planning, 39(6), 631648. https://doi.org/10.1016/j.lrp.2006.11.002 
Jarzabkowski, P., \& Seidl, D. (2008). The role of meetings in the social practice of strategy. Organization Studies, 29(11), 13911426. https://doi.org/10.1177/0170840608096388

Jarzabkowski, P., \& Wilson, D.C. (2002). Top teams and strategy in a UK university. Journal of Management Studies, 39(3), 357-383. https://doi.org/10.1111/1467-6486.00296

Jarzabkowski, P., Balogun, J., \& Seidl, D. (2007). Strategizing: The challenges of a practice perspective. Human Relations, 60(1), 5-27. https://doi.org/10.1177/0018726707075703

Jarzabkowski, P., Bednarek, R., \& Cabantous, L. (2014). Conducting global team-based ethnography: Methodological challenges and practical methods. Human Relations, 68(1), 3-33. https://doi.org/10.1177/0018726714535449

Jarzabkowski, P., Kaplan, S., Seidl, D., \& Whittington, R. (2016). On the risk of studying practices in isolation: Linking what, who, and how in strategy research. Strategic Organization, 14(3), 248-259. https://doi.org/10.1177/1476127015604125

Jarzabkowski, P. \& Spee, A. P. (2009). Strategy-as-practice: a review and future directions for the field. International Journal of Management Reviews, 11(1), 69-95. https://doi.org/10.1111/j.1468-2370.2008.00250.x

Johnson, G., Langley, A., Melin, L., \& Whittington, R. (2007). Strategy as practice. Cambridge: Cambridge University Press.

Johnson, G., Melin, L., \& Whittington, R. (2003). Micro strategy and strategizing: Towards an activity-based view. Journal of Management Studies, 40(1), 3-22. https://doi.org/10.1111/1467-6486.t01-2-00002

Johnson, G. Smith, S., \& Colding, B. (2010). Institutional change and strategic agency: an empirical analysis of managers' experimentation with routines in strategic decisionmaking. In D. Golsorkhi, L. Rouleau, D. Seidl, \& E. Vaara (Eds.), Cambridge handbook of strategy as practice (pp. 273-290). Cambridge: Cambridge University Press.

Kalou, Z., \& Sadler-Smith, E. (2015). Using ethnography of communication in organizational research. Organizational Research Methods, 18(1), 629-655. https://doi.org/10.1177/1094428115590662

Kouamé, S. \& Langley, A. (2018). Relating microprocesses to macro-outcomes in qualitative strategy process and practice research. Strategic Management Journal, 39(3), 559-581. https://doi.org/10.1002/smj.2726

Küpers, W. (2005). Phenomenology of embodied implicit and narrative knowing. Journal of Knowledge Management, 9(6), 114-133. https://doi.org/10.1108/13673270510630006

Küpers, W. (2009). The status and relevance of Phenomenology for integral research: Or Why Phenomenology is more and different than an "upper left" or "zone \#1" affair. Integral Review, 5(1), 51-95. Retrieved from https://www.researchgate.net/profile/Wendelin Kuepers/ publication/26627228 The Status and Relevance of Phenomenology for Integral Research Or Why Phenomenology is More and Different than an Upper Left or Zone 1 Affair/links/0deec52838195df031000000. pdf
Küpers, W., Mantere, S., \& Statler, M. (2013). Strategy as storytelling: A phenomenological collaboration. Journal of Management Inquiry, 22(1), 83-100. https://doi.org/10.1177/1056492612439089

Laslett, B. (1999). Personal narratives as sociology. Contemporary Sociology, 28(4), 391-401. https://doi.org/10.2307/2655287

LeCompte, M. D., \& Goetz, J. P. (1982). Problems of reliability and validity in ethnographic research. Review of Educational Research, 52(1), 31-60. https://doi.org/10.3102/00346543052001031

Lofland, J. (1995). Analytic ethnography: Features, failings, and futures. Journal of Contemporary Ethnography, 24(1), 3067. https://doi.org/10.1177/089124195024001002

Mantere, S., \& Whittington, R. (2020). Becoming a strategist: The roles of strategy discourse and ontological security in managerial identity work. Strategic Organization, online first, 1-26. https://doi.org/10.1177/1476127020908781

Miettinen, R., Samra-Fredericks, D., \& Yanow, D. (2009). Re-turn to practice: An introductory essay. Organization Studies, 30(12), 1309-1327. https://doi.org/10.1177/0170840609349860

Mills, J., Bonner, A., \& Francis, K. (2006). Adopting a constructivist approach to grounded theory: Implications for research design. InternationalJournalof Nursing Practice, 12(8), 8-13. https://doi.org/10.1111/j.1440-172X.2006.00543.x

Mintzberg, H. (1979). The structuring of organizations: A synthesis of the research. Englewood Cliffs: Prentice-Hall.

Murphy, S. A., \& O’Brien, A. (2006). Listening above the din: The potential of language in organizational research. International Journal of Qualitative Methods, 5(2), 87-110. https://doi.org/10.1177/160940690600500211

Nicolini, D. (2009a). Zooming in and out: Studying practices by switching theoretical lenses and trailing connections. Organization Studies, 30(12), 1391-1418. https://doi.org/10.1177\%2F0170840609349875

Nicolini, D. (2009b). Articulating practice through the interview to the double. Management Learning, 40(2), p. 195-212. https://doi.org/10.1177\%2F1350507608101230

Orlikowski, W. J (2010). Practice in research: phenomenon, perspective and philosophy. In D. Golsorkhi, L. Rouleau, D. Seidl, \& E. Vaara (Eds.), Cambridge handbook of strategy as practice (pp. 23-33). Cambridge: Cambridge University Press.

Paroutis, S., \& Pettigrew, A. (2007). Strategizing in the multibusiness firm: Strategy teams at multiple levels and over time. Human Relations, 60(1), 99-135. http://dx.doi.org/10.1177/0018726707075285

Patriota, G. (2003). Sensemaking on the Shop Floor: Narratives of Knowledge in Organizations. Journal of Management Studies, 40(2), 349-375. https://doi.org/10.1111/1467-6486.00343 
Pettigrew, S. F. (2000). Ethnography and grounded theory: a happy marriage? Advances in Consumer Research, 27, 256-331. Retrieved from https:/www.acrwebsite.org/volumes/8400/volumes/v27/NA-

Prus, R. (1987). Generic social processes: maximizing conceptual development in ethnographic research. Journal of Contemporary Ethnography, 16(3), 250-293. https://doi.org/10.1177/0891241687163002

Quay, J. (2016). Learning phenomenology with Heidegger: experiencing the phenomenological 'starting point' as the beginning of phenomenological research. Educational Philosophy and Theory, 48(5), 484-497. https://doi.org/10.1080/00131857.2015.1035632

Rasche, A., \& Chia, R. (2009). Researching strategy practices: A genealogical social theory perspective. Organization Studies, 30(7), 713-734. https://doi.org/10.1177/0170840609104809

Reckwitz, A. (2002). Toward a theory of social practices: A development in culturalist theorizing. European Journal of Social Theory, 5(2), 243-263. https://doi.org/10.1177/13684310222225432

Regnér, P. (2003). Strategy creation in the periphery: Inductive versus deductive strategy making. Journal of Management Studies, 40(1), 57-82. https://doi.org/10.1111/1467-6486.t01-1-00004

Rhodes, C., \& Brown, A. D. (2005). Narrative, organizations and research. International Journal of Management Reviews, 7(3), 167-188. https://doi.org/10.1111/j.1468-2370.2005.00112.x

Riessman, C. K. (1993). Narrative analysis (Vol. 30, Qualitative Research Methods). Newbury Park, CA: Sage Publications.

Rosen, M. (1991). Coming to terms with the field: Understanding and doing organizational ethnography. Journal of Management Studies, 28(1), 1-24. https://doi.org/10.1111/j.1467-6486.1991.tb00268.x

Rouleau, L. (2005). Micro-practices of strategic sensemaking and sensegiving: How middle managers interpret and sell change every day. Journal of Management Studies, 42(7), 14131441. https://doi.org/10.1111/j.1467-6486.2005.00549

Rouleau, L. (2006). Comprendre la fabrique de la stratégie à partir des récits de pratiques. In D. Golsorkhi. (Ed.). La fabrique de la stratégie: une perspective multidimensionnelle. Paris: Institut Vital Roux-Librairie Vuibert.

Rouleau, L. (2010). Studying strategizing through narratives of practice. In D. Golsorkhi, L. Rouleau, D. Seidl, \& E. Vaara (Eds.), Cambridge Handbook of Strategy as Practice (pp. 258-270). Cambridge: Cambridge University Press.

Samra-Fredericks, D. (2003). Strategizing as lived experience and strategists' everyday efforts to shape strategic direction. Journal of Management Studies, 4O(1), 142-174. https://doi.org/10.1111/1467-6486.t01-1-00007

Sanders, P. (1982). Phenomenology: a new way of viewing organizational research. Academy of Management Review, 7(3), 353-360. https://doi.org/10.5465/amr.1982.4285315
Sandberg, J., \& Dall'Alba, G. (2009). Returning to practice anew: A life-world perspective. Organization Studies, 30(12), 1349_ 1368. https://doi.org/10.1177/0170840609349872

Schatzki, T. R. (1996). Social practice: A wittgensteinian approach to human activity and the social. Cambridge: Cambridge University Press.

Schatzki, T. R. (2002). The site of the social: A philosophical account of the constitution of social life and change. Pennsylvania: Pennsylvania State University.

Schatzki, T. R. (2005). Peripheral vision: The sites of organizations. Organization Studies, 26(3), 465-484. https://doi.org/10.1177/0170840605050876

Schatzki, T. R., Knorr-Cetina, K., \& Savigny, E. von. (2001). The practice turn in contemporary. London: Routledge.

Seidl, D., \& Whittington, R. (2014). Enlarging the strategyas-practice research agenda: Towards taller and flatter ontologies. Organization Studies, 35(10), 1407-1421. https://doi.org/10.1177/0170840614541886

Shepherd, D. A., \& Suddaby, R. (2017). Theory building: A review and integration. Journal of Management, 43(1), 59-86. https://doi.org/10.1177/0149206316647102

Snow, D. A., Morrill, C., \& Anderson, L. (2003). Elaborating analytic ethnography: Linking fieldwork and theory. Ethnography, 4(2), 181-200. https://doi.org/10.1177/14661381030042002.

Soin, K., \& Scheytt, T. (2006). Making the case for narrative methods in cross-cultural organizational research. Organizational Research Methods, 9(1), 55-77. https://doi.org/10.1177/1094428105283297

Sorsa, V., \& Vaara, E. (2020). How can pluralistic organizations proceed with strategic change? a processual account of rhetorical contestation, convergence, and partial agreement in a nordic city organization. Organization Science, online first, 1-26. https://doi.org/10.1287/orsc.2019.1332

Spradley, J. P. (1979). The ethnographic interview. Belmont: Wadsworth Group \& Thomson Learning.

Strauss, A., \& Corbin, J. (1998). Basics of qualitative research: Grounded theory procedures and techniques. Newbury Park: Sage Publications.

Suddaby, R. (2006). What grounded theory is not. Academy of Management Journal, 49(4), 633-642. https://doi.org/10.5465/amj.2006.22083020

Suddaby, R., Seidl, D., \& Lê, J. K. (2013). Strategy-as-practice meets neo- institutional theory. Strategic Organization, 11(3), 329-344. https://doi.org/10.1177/1476127013497618

Tsoukas, H. (2010). Practice, strategy making and intentionality: A Heideggerian onto-epistemology for Strategy as Practice. In D. Golsorkhi, L. Rouleau, D. Seidl, \& E. Vaara. (Eds.), Cambridge handbook of strategy as practice (pp. 47-62). Cambridge: Cambridge University Press.

Tsoukas, H. (2018). Strategy and virtue: Developing strategy-aspractice through virtue ethics. Strategic Organization, 16(3) 323-351. https://doi.org/10.1177/1476127017733142 
Vaara E., Sonenshein, S., \& Boje, D. (2016). Narratives as sources of stability and change in organizations: approaches and directions for future research. Academy of Management Annals, 10(1), 495-560. https://doi.org/10.1080/19416520.2016.1120963

Vaara, E., \& Whittington, R. (2012). Strategy-aspractice: Taking social practices seriously. The Academy of Management Annals, 6(1), 285-336. https://doi.org/10.1080/19416520.2012.672039

Van Manen, M. (1984). Practicing phenomenological writing. Phenomenology + Pedagogy, 2(1), 36-69. https://doi.org/10.29173/pandp14931

Van Maanen, J. (1988). Tales of the field: On writing ethnography. Chicago: University of Chicago Press.

Van Maanen, J., Sørensen, J. B., \& Mitchell, T. R. (2007). The interplay between theory and method. Academy of Management Review, 32(4), 1145-1154. https://doi.org/10.5465/amr.2007.26586080

Vesa, M., \& Vaara, E. (2014). Strategic ethnography 2.0: Four methods for advancing strategy process and practice research. Strategic Organization, 12(4), 288-298. https://doi.org/10.1177/1476127014554745

Vom Lehn, D., \& Hitzler, R. (2015). Phenomenology-based ethnography: Introduction to the special issue. Journal of Contemporary Ethnography, 44(5), 539-543. https://doi.org/10.1177/0891241615595436

Walsh, I., Holton, J. A., Bailyn, L., Fernandez, W., Levina, N., \& Glaser, B. (2015). What grounded theory is... A critically reflective conversation among scholars. Organizational Research Methods, 18(4), 581-599. https://doi.org/10.1177/1094428114565028

Watson, T. J. (2011). Ethnography, reality, and truth: The vital need for studies of 'how things work' in organizations and management. Journal of Management Studies, 48(1), 202217. https://doi.org/10.1111/j.1467-6486.2010.00979.x
Watson, T. J., \& Watson, D. H. (2012). Narratives in society, organizations and individual identities: An ethnographic study of pubs, identity work and the pursuit of 'the real'. Human Relations, 65(6), 683-704. https://doi.org/10.1177/0018726712440586

Whittle, A., Gilchrist, A., Mueller, F., \& Lenney, P. (2020). The art of stage-craft: A dramaturgical perspective on strategic change. Strategic Organization, online first, 1-31. https://doi.org/10.1177/1476127020914225

Whittington, R. (2004). Estratégia após o modernismo: recuperando a prática. Revita de Administração de Empresas, 44(4), 4453.

Whittington, R. (1996). Strategy as practice. Long Range Planning, 29(5), 731-735. https://doi.org/10.1016/0024-6301(96)00068-4

Whittington, R. (2006). Completing the practice turn in strategy research. Organization Studies, 27(5), 613-634. https://doi.org/10.1177/0170840606064101

Whittington, R. (2010). Giddens, structuration theory and Strategy as Practice. In D. Golsorkhi, L. Rouleau, D. Seidl, \& E. Vaara (Eds.). Cambridge handbook of strategy as practice (pp. 109-126). Cambridge: Cambridge University Press.

Whittington, R. (2011). The practice turn in organization research: towards a disciplined transdisciplinarity. Accounting, Organizations and Society, 36, 183-186. https://doi.org/10.1016/j.aos.2011.04.003

Whittington, R., Cailluet, L., \& Yakis-Douglas, B. (2011). Opening strategy: Evolution of a precarious profession. British Journal of Management, 22(3), 531-544. https://doi.org/10.1111/j.1467-8551.2011.00762.x

Willems, T. (2018). Seeing and sensing the railways: A phenomenological view on practice-based learning. Management Learning, 49(1), 23-39. https://doi.org/10.1177/1350507617725188

Wolf, C., \& Floyd, S. W. (2017). Strategic planning research: Toward a theory-driven agenda. Journal of Management, 43(6), 1754-1788. https://doi.org/10.1177/0149206313478185 


\section{Authorship}

\section{Leonardo Lemos da Silveira Santos}

Universidade Federal de Juiz de Fora, Departamento de Administração

Rua São Paulo, no 745, Centro, 35010-180, Governador Valadares, MG, Brazil.

E-mail address: lemos.santos.leo@gmail.com

(1) https://orcid.org/0000-0002-8227-8203

\section{César Tureta*}

Universidade Federal do Espírito Santo, Programa de Pósgraduação em Administraçáo

Av. Fernando Ferrari, no 514, Goiabeiras, 29075-910, Vitória, ES, Brazil.

E-mail address: cesartureta.ufes@gmail.com

(1) https://orcid.org/0000-0003-0091-1114

\section{Bruno Felix}

FUCAPE Business School

Av. Fernando Ferrari, no 1358, Goiabeiras, 29075-505, Vitória, ES, Brazil.

E-mail address: bfelix@fucape.br

(1) https://orcid.org/0000-0001-6183-009X

* Corresponding Author

\section{Funding}

There are no funders to report for this article.

\section{Conflict of Interests}

The authors have stated that there is no conflict of interest.

\section{Authors' Contributions}

$1^{\text {st }}$ author: conceptualization (lead); data curation (equal); formal analysis (equal); supervision (equal); validation (equal); visualization (equal); writing-original draft (equal); writing-review \& editing (equal).

$2^{\text {nd }}$ author: conceptualization (supporting); data curation (equal); formal analysis (equal); supervision (equal); validation (equal); visualization (equal); writing-original draft (equal); writing-review \& editing (equal).

$3^{\text {rd }}$ author: conceptualization (supporting); data curation (equal); formal analysis (equal); supervision (supporting); validation (equal); visualization (equal); writing-original draft (equal); writing-review \& editing (supporting).

\section{Copyrights}

RAC owns the copyright to this content.

\section{Plagiarism Check}

The RAC maintains the practice of submitting all documents approved for publication to the plagiarism check, using specific tools, e.g.: iThenticate.

\section{Peer Review Method}

This content was evaluated using the double-blind peer review process. The disclosure of the reviewers' information on the first page, as well as the Peer Review Report, is made only after concluding the evaluation process, and with the voluntary consent of the respective reviewers and authors. 